\title{
THE TOOL SURFACE WEAR DURING THE SILICON STEEL SHEETS BLANKING PROCESS
}

\section{ZUŻYCIE POWIERZCHNI NARZĘDZI PODCZAS EKSPLOATACJI W PROCESIE WYKRAWANIA BLACHY KRZEMOWEJ*}

\begin{abstract}
The surface wear mechanism of punches for the silicon sheets blanking was presented. In the studies the differences in the wear of high-speed tool (produced by casting and sintering), where observed. The influence of additional TiN coating on the punches flank degradation intensity was obtained. The strengthening zone changes of the sheared blank material close to cutting line were observed. The punch wear influence on the M530-50A silicon sheet material hardness changes was described.
\end{abstract}

Keywords: tool wear, high-speed steel, blanking process, silicon steel sheets.

\begin{abstract}
W niniejszym artykule przedstawiono opis mechanizmu zużycia powierzchni roboczych stempli wykrawajacych elementy z blachy krzemowej. Badania wykazały różnice w zużyciu narzędzi dla stali szybkotnacej w przypadku dwóch procesów jej wytwarzania (odlewania i spiekania). Wykazano wpływ dodatkowej powłoki z TiN na intensywność degradacji powierzchni przyłożenia stempli wykrawających. Obserwacji poddano zmiany obszaru umocnienia materiatu wykrawanego w pobliżu linii cięcia. Określono wplyw zużycia stempli na zasięg zmian twardości materiatu blachy krzemowej M530-50A.
\end{abstract}

Stowa kluczowe: zużycie narzędzi, stale szybkotnace, wykrawanie, blachy krzemowe.

\section{Introduction}

Production of the sheared blank elements, with a certain quality, requires an optimal process parameters selection $[4,6,11,30]$. Gréban et al. in their work [6] presented the effects of copper alloy elements blanking process. Tekiner et al. [30] described the result of experimental analysis of the aluminum alloy element blanking process. Hernández and other authors [11] presented the influence of the punch cutting edge geometry changes on the cut surface quality. They described the influence of the blanking process clearance and punch diameter. The study concerned the acid resistant steel sheet (AISI 304). There is some dependence between the burr height changes and the punch wear during the blanking process. Study of the high-steel punch wear, for punches with front edge slopped, was presented by Cheung et al. [4]. Blanking process causes the sheet material structure changes. The case of aluminum element blanking process was analyzed by Ravela et al. [28]. The tool surface wear during the blanking process causes changes of the cut surface quality $[8,9,14,17 \div 19]$. The value of the cutting edge radius significantly affects on the blanking process energy consumption [16]. Tool wear, geometry and clearance influence on the burr height. The bur height can be reduced by using an appropriate tool arrangement.

Electrical steel sheets used in electrical machines have a relatively high induction, permittivity and good punchability. The sheet material magnetic properties are determined in the production process [31]. For the evaluation of the sheet punchability many criterions can be used, and the most important are:

- sheared blank part deformation resistance,

- the burr height,

- coating damage resistant during blanking process,

- material strengthening close to the cut surface,

- geometrical quality of the sheared blank sheet material,
- cutting tools durability,

- intersection surface quality of the sheared blank parts.

The excessive tool wear during the blanking process causes significant changes of the size and zone of plastic deformation concentration in sheared blank element close to the intersection surface [23, 24]. In the deformed silicon steel sheet the undesirable magnetic residue appears, which impairs the sheet magnetic properties - including the increase of the electrical current required for the sheet grains over-magnetization during the voltage transformation [31]. The phenomenon of eddy currents abnormal flow is useful in other situations and is commonly used in the surface quality measurements and in an analysis of the internal defects in element after their operation [13]. In the electrical machine case, it is not preferred to increasing of the magnetic lossiness especially in the sheets used for rotors and stators of the asynchronous motors [24]. One of the manufacturing methods, that reduce the magnetic lossiness is laser cutting process, but it is expensive and has a relatively low productivity [27]. Thus, the blanking process is still used for the rotor and stator plates manufacturing. Many studies are related with the analysis of the magnetic lossiness and magnetic disturbance in the sheets produced by various techniques $[5,15,20,27,32]$. Typical materials used for blanking tools are high-speed steels such as: M2, K945, M35, M42, ASP23, ASP30, ASP60 (ASP-Asea Stora Process).

In the paper the tools wear during the blanking process of the silicon steel sheets was presented. Observation was made at the micro and macro level. The mechanism of the punch surface wear was described. The influence of the punch edge wear on the medium stress distribution in sheared blank material, by using FEM, was presented.

(*) Tekst artykułu w polskiej wersji językowej dostępny w elektronicznym wydaniu kwartalnika na stronie www.ein.org.pl 


\section{Sheet and tools material char-} acteristic

The silicon steel sheets M530-50A (M 45 according to AISI) (PN-EN 10106:201601) [26], with thickness $g=0,5 \pm 0,02 \mathrm{~mm}$ were used in experiments. Sheets used in blanking process of electrical machine parts are produced by cold rolling. The M530-50A sheet material has got $1.54 \mathrm{~T}$ induction at $2500 \mathrm{~A} / \mathrm{m}$ electrical current

Table 3. Chemical composition of punch materials [\%]

\begin{tabular}{|c|c|c|c|c|c|c|c|c|c|c|}
\hline \multirow[b]{2}{*}{ Materiał } & \multicolumn{9}{|c|}{ Dodatki pierwiastków } & \multirow[b]{2}{*}{$\mathrm{Fe}$} \\
\hline & $C$ & $\begin{array}{l}\text { Mn } \\
\max \end{array}$ & $\underset{\max }{\mathbf{S i}}$ & $\underset{\max }{\mathbf{P}}$ & $\underset{\max }{\mathbf{S}}$ & $\mathrm{Cr}$ & $\mathbf{W}$ & Mo & V & \\
\hline $\begin{array}{c}\text { M2 } \\
\text { (SW7M) }\end{array}$ & $0,82-0,92$ & 0,4 & 0,5 & 0,03 & 0,03 & $3,5-4,5$ & $6,0-7,0$ & $4,5-5,5$ & $1,7-2,1$ & reszta \\
\hline $\begin{array}{c}\text { M3:2 } \\
\text { (ASP 23) }\end{array}$ & $1,19-1,21$ & - & - & - & - & $4,11-4,13$ & $6,33-6,37$ & $4,6-4,8$ & $3,1-3,2$ & reszta \\
\hline
\end{tabular}

Table 1. Mechanical properties of M530-50A silicon steel sheets material

\begin{tabular}{|c|c|c|c|c|c|c||}
\hline $\begin{array}{c}\mathrm{R}_{0.2} \\
{[\mathrm{MPa}]}\end{array}$ & $\begin{array}{c}\mathrm{R}_{\mathrm{m}} \\
{[\mathrm{MPa}]}\end{array}$ & $\begin{array}{c}\mathrm{Z} \\
{[\%]}\end{array}$ & $\begin{array}{c}\mathrm{A} 5 \\
{[\%]}\end{array}$ & $\begin{array}{c}\text { So } \\
{\left[\mathrm{mm}^{2}\right]}\end{array}$ & HV5 & $\begin{array}{c}\mathrm{E} \\
{[\mathrm{MPa}]}\end{array}$ \\
\hline 245 & 417 & 33 & 61 & 10 & 126 & $2,2 \mathrm{e}+5$ \\
\hline
\end{tabular}

Table 2. Chemical composition of M530-50A silicon sheet material (\%)

\begin{tabular}{|c|c|c|c|c|c|c|c|c|c||}
\hline \hline $\mathrm{P}$ & $\mathrm{C}$ & $\mathrm{Si}$ & $\mathrm{S}$ & $\mathrm{Mn}$ & $\mathrm{Cr}$ & $\mathrm{Ni}$ & $\mathrm{Cu}$ & $\mathrm{Al}$ & $\mathrm{Fe}$ \\
\hline 0,01 & 0,01 & 1,43 & 0,007 & 0,365 & $<0,01$ & $<0,01$ & 0,05 & 0,335 & reszta \\
\hline
\end{tabular}

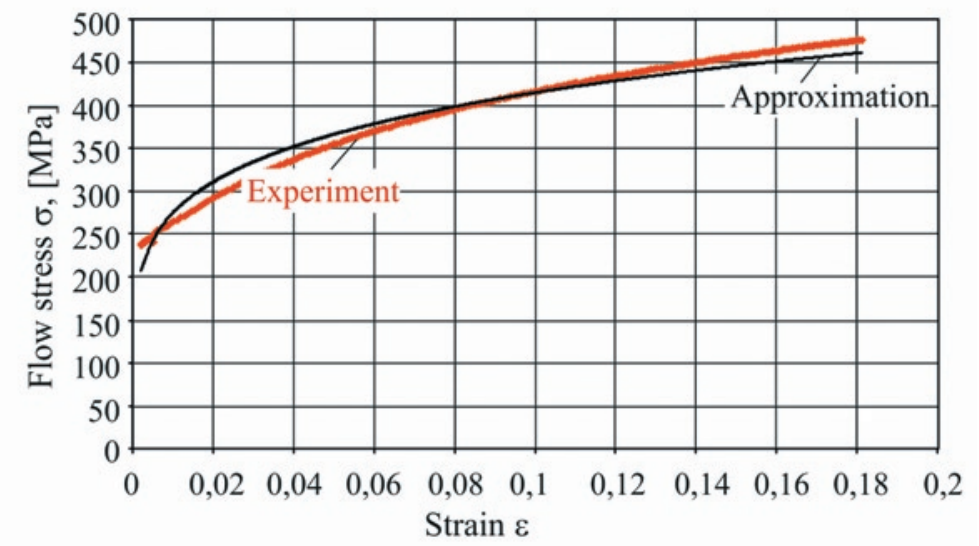

Fig. 1. Experimental hardening curve (thick line) and Hollomon equation approximation (thin line; correlation coefficient: 0,968)

and 5,3 W/kG electrical lossiness at $1.5 \mathrm{~T}$ induction. The main mechanical properties and chemical compositions were presented in Table 1 and Table 2. The sheet has a C6 insulating coating (according to AISI ASTM A976 [1]) of thickness $\sim 7 \pm 1,5 \mu \mathrm{m}$ on each side.

Materials used on cutting tools have different mechanical properties, which determine the tool surfaces wearing out during the blanking process [2]. For experimental analysis the punches were made of: M2, M3:2 materials (Fig. 2), and M2+TiN, M3:2+TiN materials with coatings. The chemical compositions of punch materials were presented in Table 3. The M3:2 (ASP 23 Vanadis, Powder Metallurgically Produced High Speed Steel) steel is a
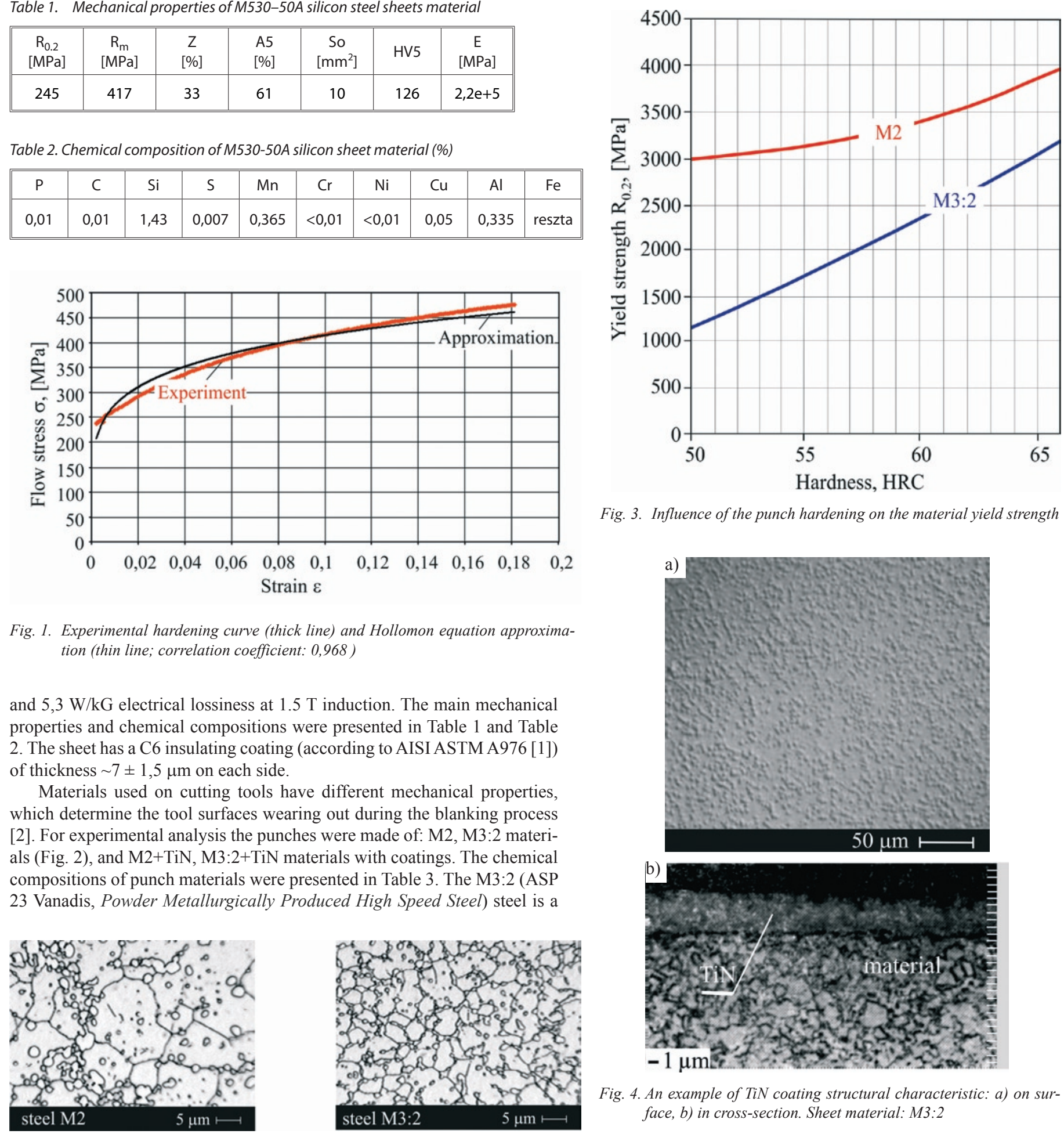

Fig. 3. Influence of the punch hardening on the material yield strength

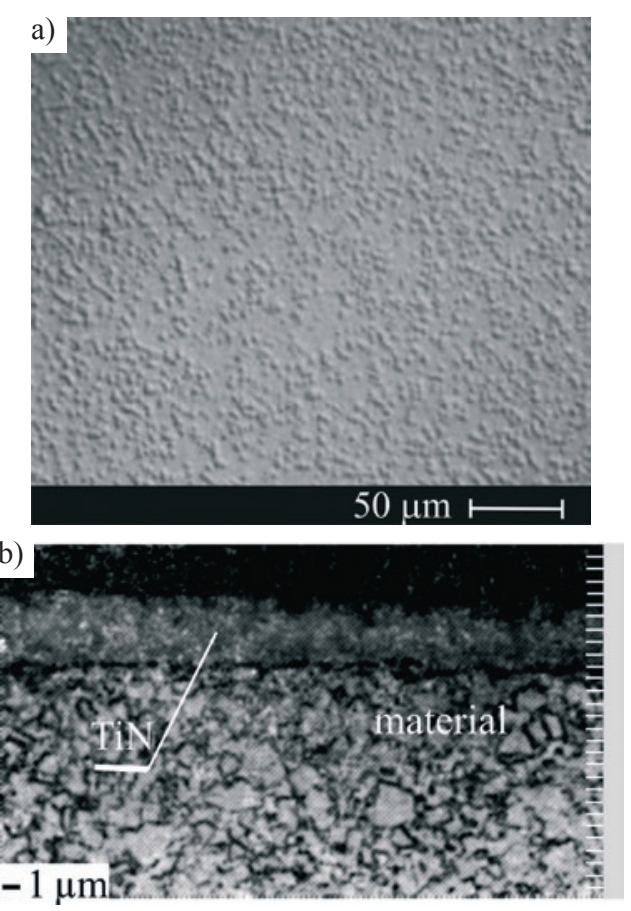

Fig. 4. An example of TiN coating structural characteristic: a) on surface, b) in cross-section. Sheet material: M3:2

Fig. 2. An example of hardened punch material structure 
material with $7980 \mathrm{~kg} / \mathrm{m}^{3}$ average density and $66 \mathrm{HRC}$ after toughening, and M2 material has an $7750 \mathrm{~kg} / \mathrm{m}^{3}$ average density and $63 \mathrm{HRC}$. The punch materials structure after hardening was shown in Figure 2, and the influence of the materials hardness on the yield strength was presented in Figure 3. The inserts in the bottom part of blanking die were made of G40 sintered carbide material.

Punch coatings were made by using PVD method (Physical Vapour Deposition). The titanium nitride coatings on the tool surface was applied at $10^{-3} \div 10^{-2} \mathrm{~Pa}$ working pressure. Applied TiN coating had a yield color, $2300 \mathrm{HV} 5$ hardness and $3,5 \div 4 \mathrm{~mm}$ thickness. The microstructure of the punch surface with TiN coating was presented in Figure 4a, and in Figure 4b the cross-section of the TiN layer on the punch was shown.

\section{Blanking punch operating conditions}

The blanking process was carried out at the press and blanking die in industrial conditions. The wear tests were carried out during the blanking process of the rotor and stator plates (Fig. 5), for low power asynchronous motor.

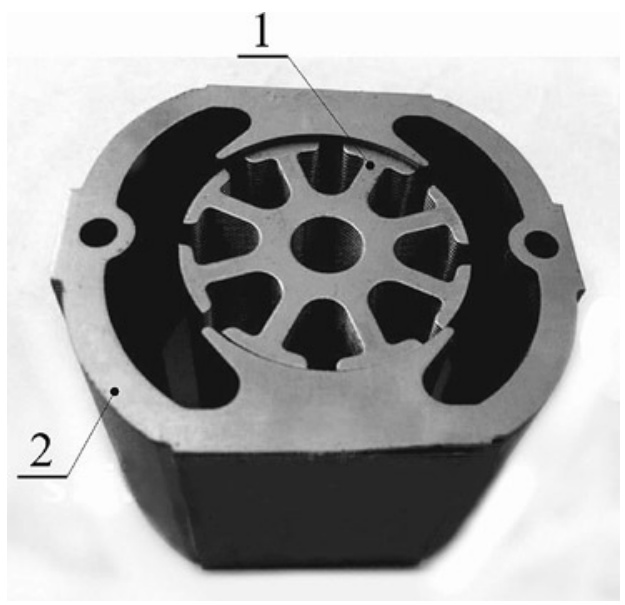

Fig. 5. Sheet packets of the rotor (1) and stator (2), M530-50A silicon steel sheet material

The use of different values of punch-die clearances and various blanking tools materials helped explain the tool wear mechanism during blanking process of the silicon steel sheet. Research conducted with this issue provide the basis for M530-50A sheets punchability analysis. The punch-die clearance $0 \%$ and $8 \%$ was defined by:

$$
L z=\frac{s}{g} \cdot 100[\%]
$$
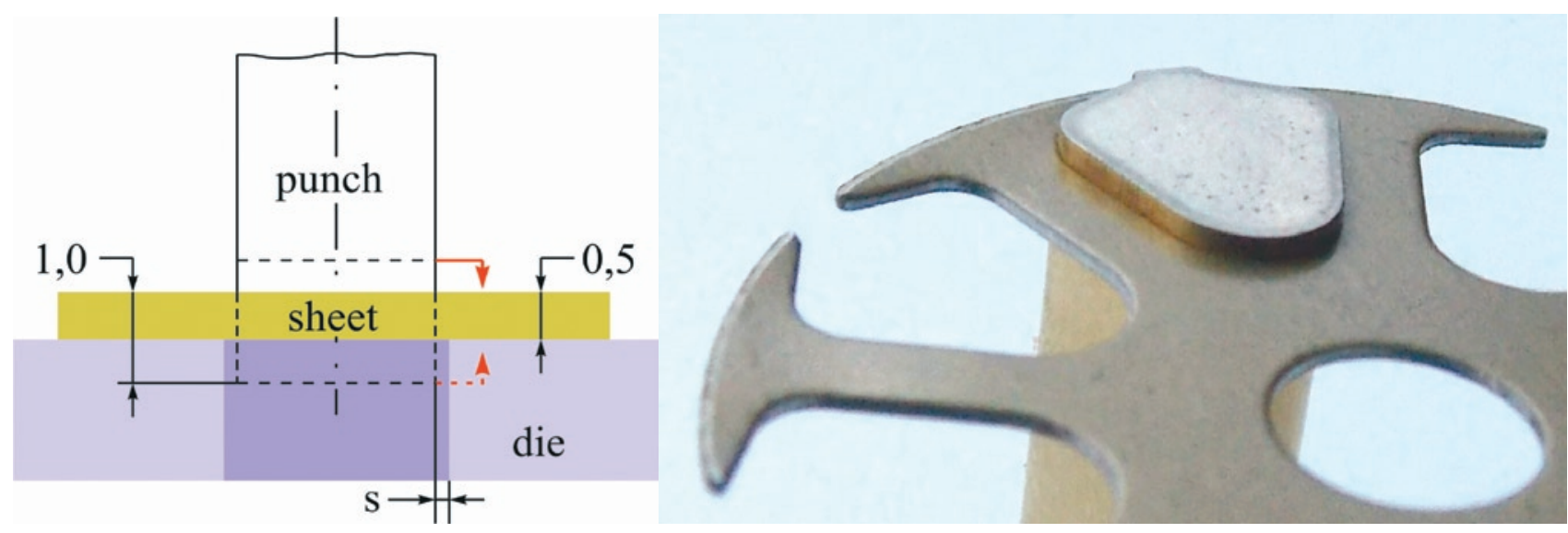

Fig. 6. Characteristic of tool and sheared blank sheets arrangement a) scheme, b) punch maximum bottom position where:

$g$ - sheet thickness,

$s$ - punch-die blanking clearance.

The relative blanking clearance has an impact on the sheet material process separation, and determines the cut surface quality [12]. The punch-die clearance is especially important during the blanking process of very small elements [10]. The blanking speed was constant, and its value was as in typical industrial process of silicon steel sheets blanking (200 cuts/min). The blanking speed is one of the blanking process technological parameters. It has an impact on the cut surface quality and the value of the blanking force [29]. The process of sheets blanking was carried out up to 800000 cuts. After the 800 thousand cuts the tools were resharpened to eliminate the cutting edge degradation and flank surface wear.

\section{Tool surface structure changes observation}

The punches during the blanking process were unleashed to flank surface wear on the surface corresponding to the sheets thickness and value of the distance necessary to forcing through the sheared blank from the separation zone. On the punch made of M2 material after 500000 cuts some signs of wear on flank surface appeared. The scratches and grooves on the analyzed surface were occurred in different extent. The deep grooves and scratches are the material loss on the punch cutting surfaces. The products of an abrasive wear, like abraded and crushed small hard particles, during the blanking process were presented in Figure 7a. This particles under pressure adhered to the tool surface. This is adhesive wear of tool surfaces. Hard particles adhered to the punch affect on the flank surface defecting during the blanking process. For the M3:2 material the particles adhered boundary is clearly visible (Fig. 7b). The adhered particles concentration was observed on the ends of contact line between material and punch. On the surface between cutting edge and end of material-punch line contact the scratches were observed.

When the punch and sheets friction surfaces are closing to each other at distance of molecular force acting, they are tacking (Fig. 8). "Adhesions" formed in this way are tearing during the punch movement. Thus, there is new adhered particles formation and grooving on the punch movement direction. During the pressure contact of two surfaces the most common wear is an abrasive wear. This wear can proceed in two ways: contact of three bodies (Fig. 9a) and contact of two bodies (Fig. 9b). In both case in micro scale, the abrasive process between harder particles and lower hardness material is observed. When separated particles are very large and hard they can force in the material with lower hardness and make the grooves during the punch movement. Intensification of tool abrasive wear and other degradation mechanism will occur in the case of accumulation of the abrasion-induced microparticles. 

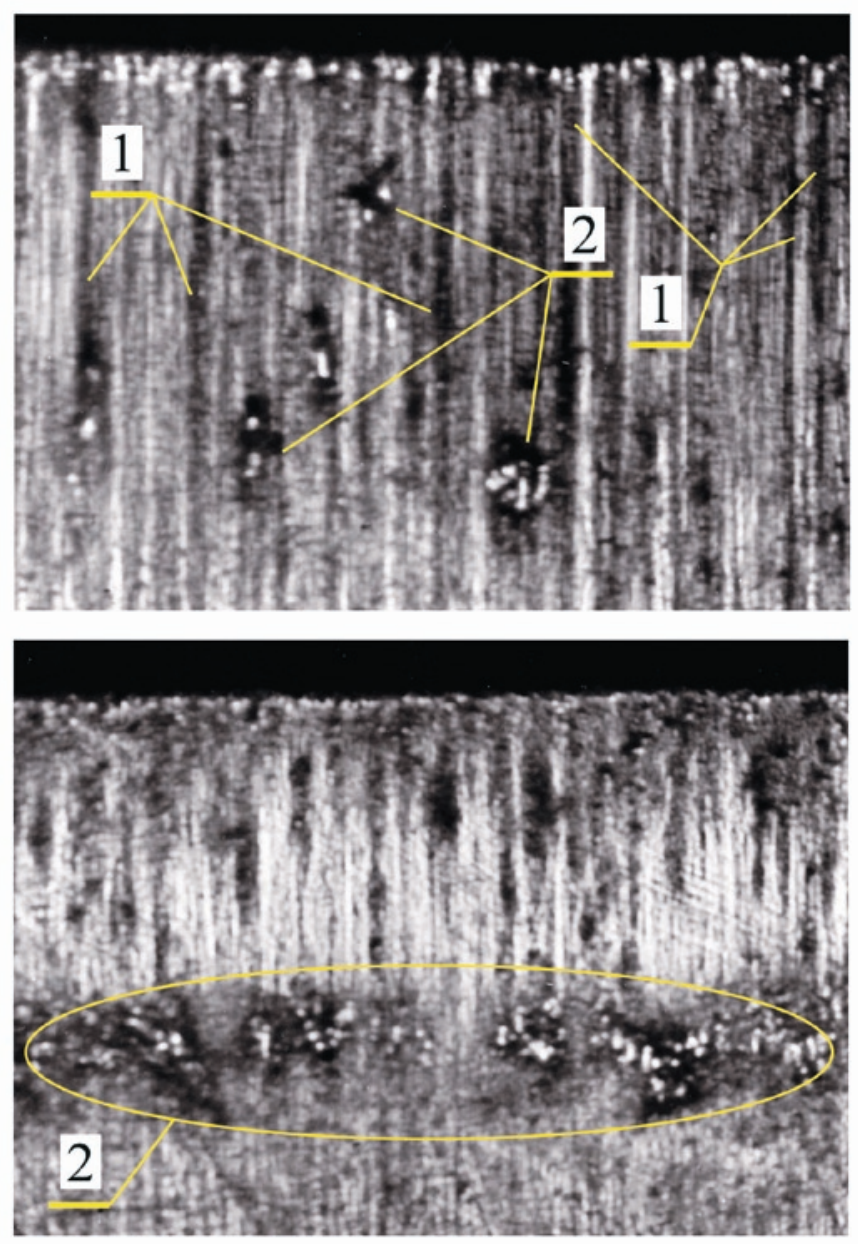

Fig. 7. Punch flank surface after 500000 sheared blanks: a) M2; x80 zoom, b) M3:2; x160 zoom
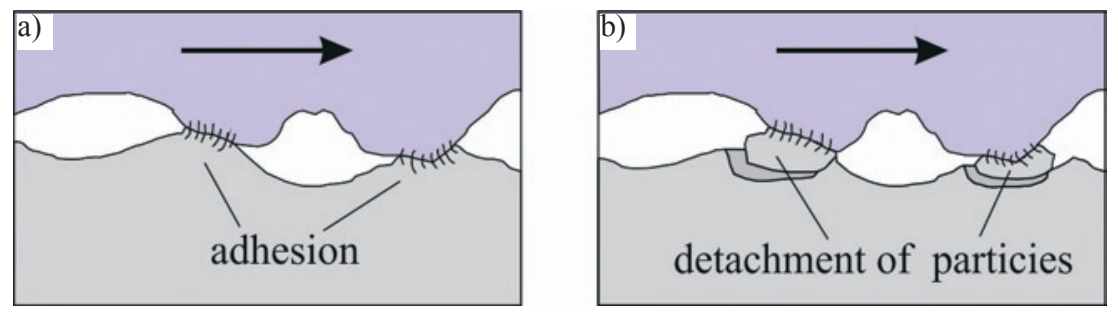

Fig. 8. Scheme of the adhesive wear: a)adhesion, b) detachment of particies
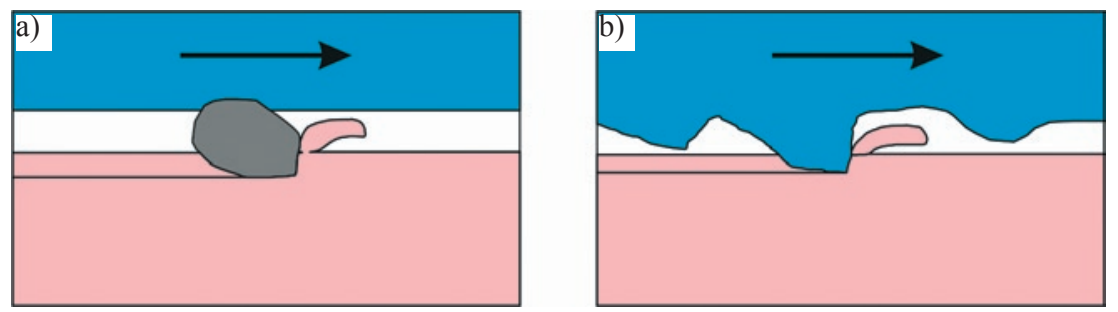

Fig. 9. Abrasive wear scheme for the contact of: a) three bodies, b) two surfaces

Initially, on whole punch circumference the contact with the unleashed silicon steel sheets caused abrasive wear mechanism (Fig. 10). On Figure 10 the punch flank surface after a several thousand cuts was presented. The dark band around the punch circumference shows the changes in the TiN coating structure. The structure changes intensity was observed by using optical equipment after a larger number of cuts.

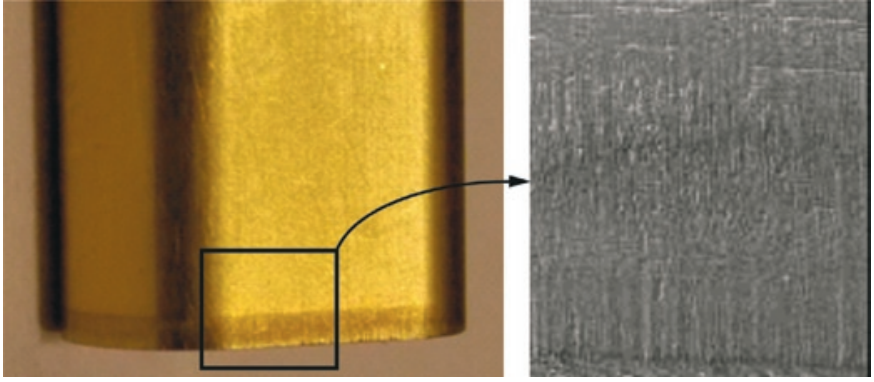

Fig. 10. Punch flank surface after a several thousand cuts $\left(L_{z}=0 \%\right.$, $M 3: 2+T i N)$

mm $1,0 \quad 0,90,8 \quad 0,7 \quad 0,6 \quad 0,5 \quad 0,4 \quad 0,3 \quad 0,2 \quad 0,1 \quad 0$

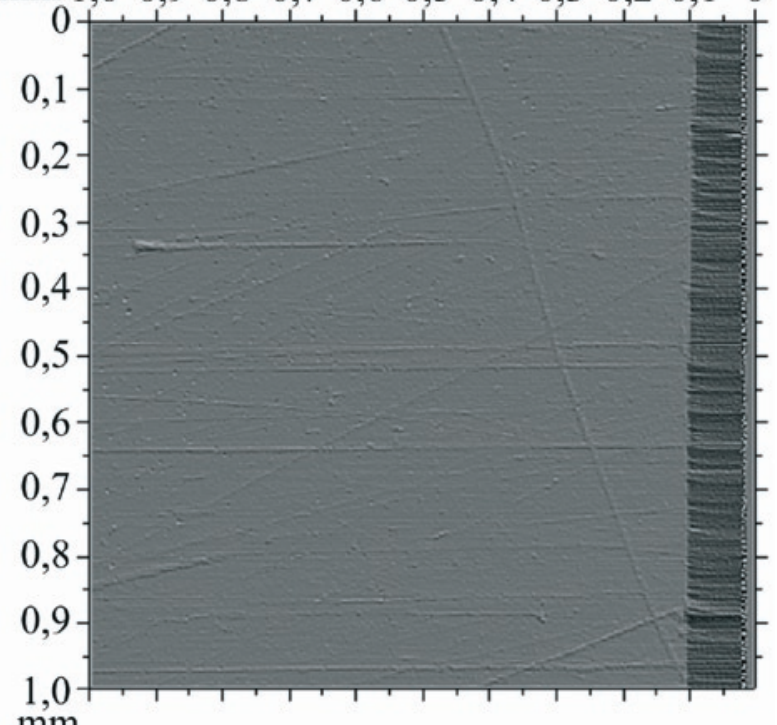

Fig. 11. The image of the punch flank surface close to cutting edge after 500000 cuts with 8\% blanking clearance (M3:2+TiN material)

The M3:2 steel produced by powder sintering technology has a slightly different structure than M2 (Fig.2). The structure of sintered steel is close-grained structure and homogeneous (right side in Fig. 2). These two materials differ in dependence between yield stress and HRC hardness function (Fig. 3). The steel sintering technology ensures obtaining the austenite fine grain and uniform distribution of carbides in sheet structure, which is impossible to achieve by conventional methods. The M2 steel has a higher ductility, so therefore is more susceptible on grooving damaging. Reduction of this phenomena intensity can be obtained by using titanium nitride coatings. For tools made of M3:2 steel due to the structure refinement abrasive wear and microspallings close to cutting edge, which deeply scratch the punch flank surface, were observed (Fig. 11).

The solid inclusion of silicon steel sheet material resulted in punch surface pressure (Fig. 12). After unleashing the silicon steel sheet the contact of hard inclusions in silicon steel sheet with inclusion in punch material was obtained. As a result of cyclical repletion of this process the gradual degradation of the tools surface with a mixes destruction mechanism occurred (grooving and spalling). The spalling forming scheme was presented in Figure 12. In the case of tools with TiN coatings in certain regions of the tools the microdamages of hard TiN layer were observed (Fig. 13). 


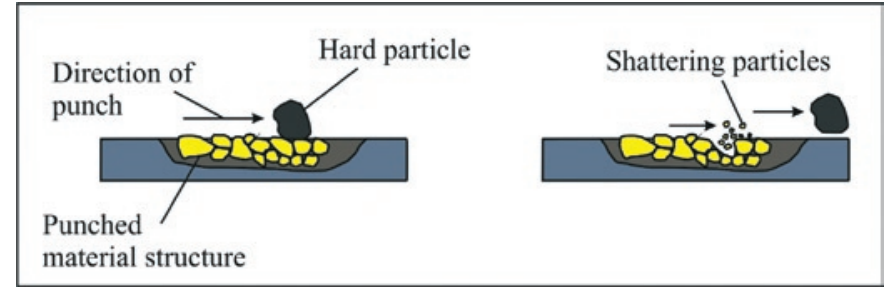

Fig. 12. Contact of the hard inclusion of the punch and sheets, and spalling mechanism

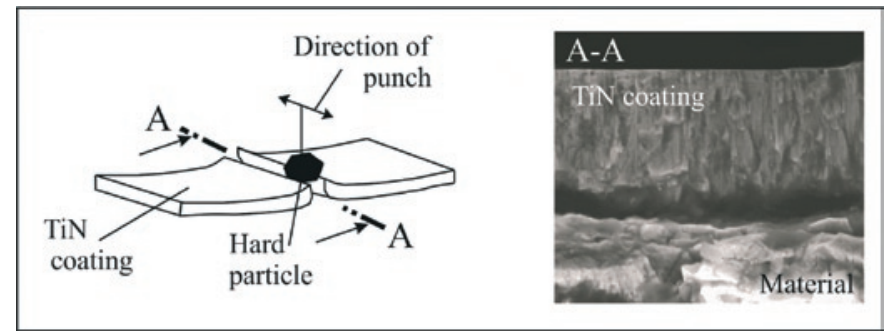

Fig. 13. Delamination between coating and surface caused by the hard inclusion in the sheared blank material

c)

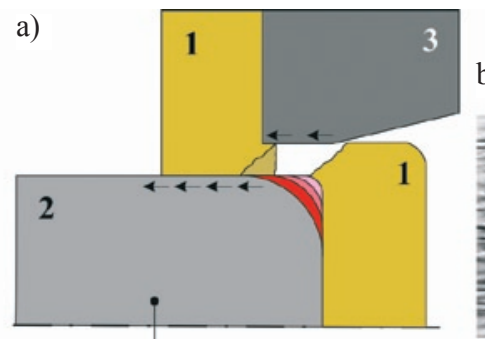

b)
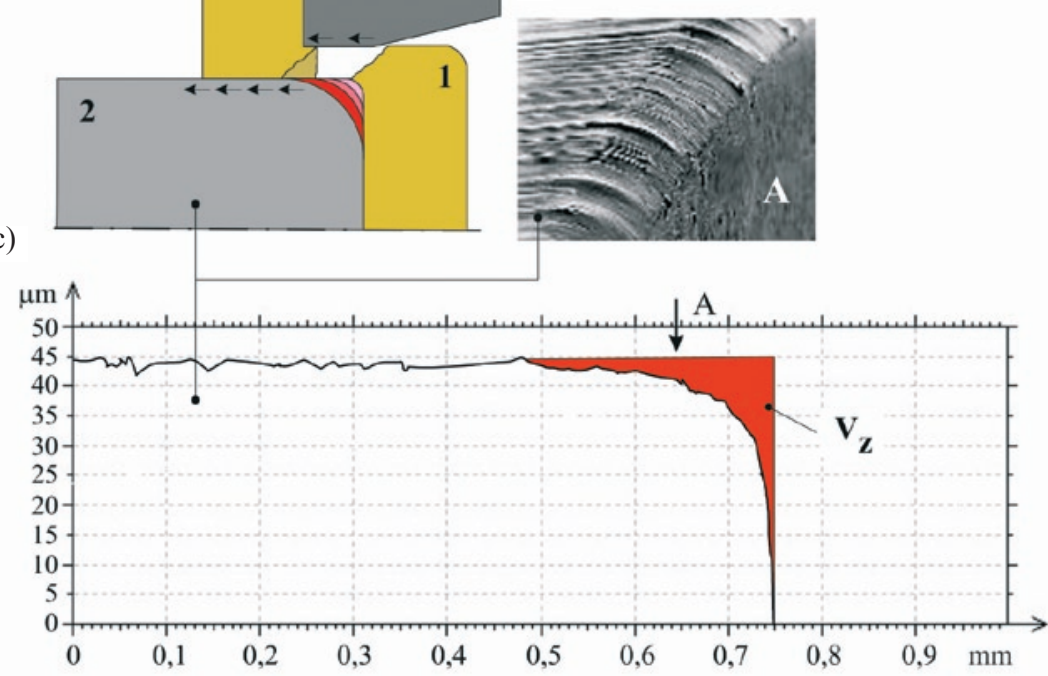

d)
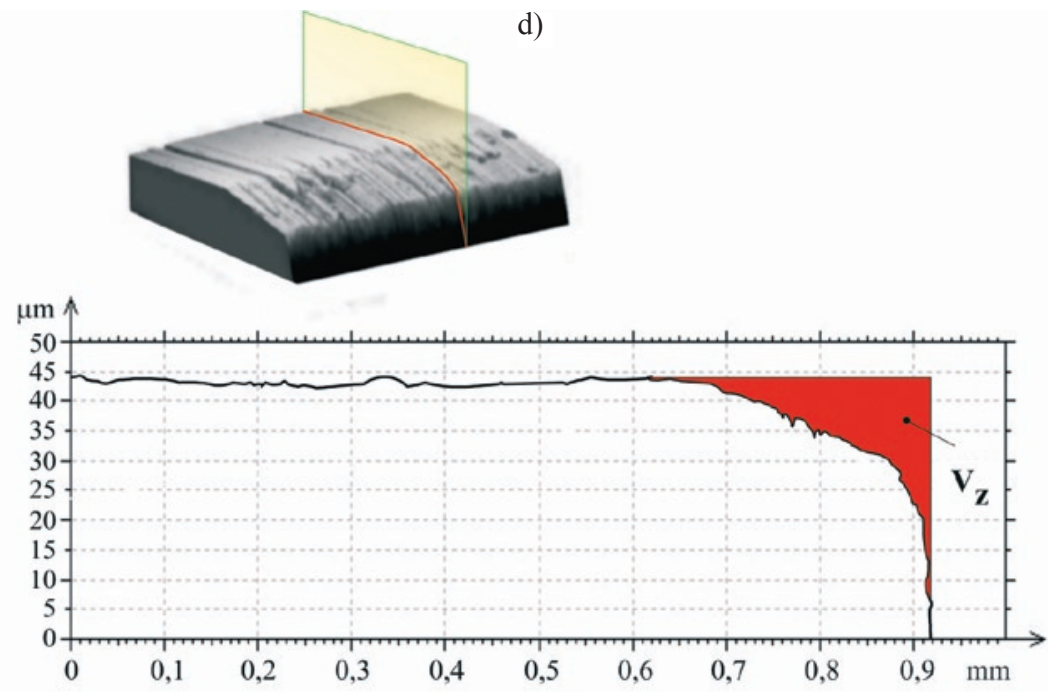

Fig. 14. Ttool cutting edge changes after 800000 cuts: a) conventional wear process (1-sheet, 2- punch, 3- shearing die), b) structure of degradation, c) punch profile for the $L_{z}=8 \%$ clearance; d) punch profile for the $L_{z}=0 \%$ clearance

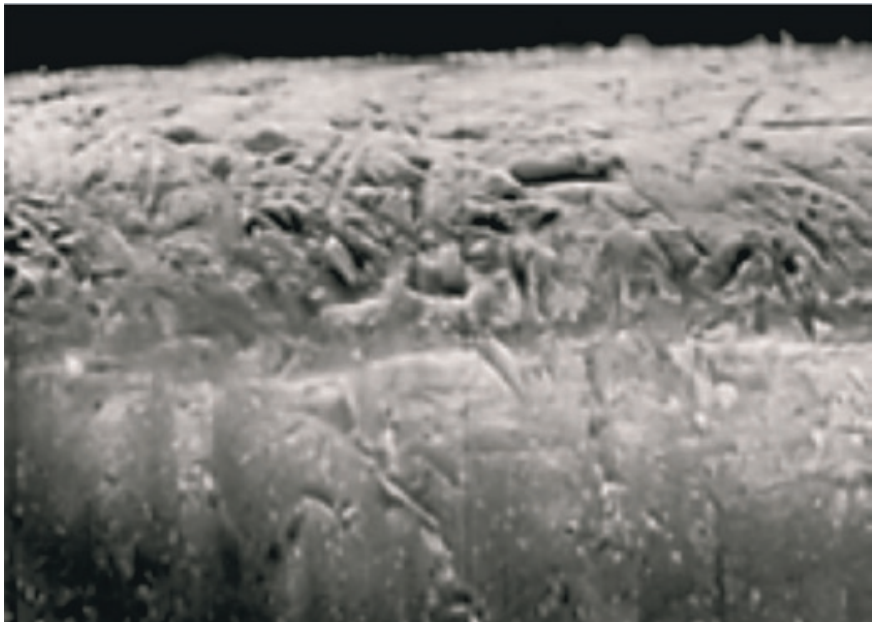

Fig. 15. Cutting edge from on the flank side (M2+TiN after 500000 cuts; $x 500$ zoom; $L_{z}=8 \%$ )

The tool wear is depended on the blanking process parameters, sheared blanks materials and tools materials. It also depends on the tools protective coatings and the technology of coating manufacturing [21]. All these issues have an influence on the blanking process energy consumption and on the cutting tool wear [3]. For the 800000 cuts the greatest wear was obtained for the $0 \%$ punch-die clearance (Fig. 14). With increasing number of cuts the abrasion product are adhered and moved with the punch movement. In the case of a strong adhesion of coating and adhered particles the TiN layer degradation and punch material unleashing can be obtained (Fig. 15).

The cutting tools topographic zones were scanned by using Taylor Hobson Ltd scanning head. On Figure 16 and 17 some examples of tool surface scanned by $3 \mathrm{D}$ scanning head and observed on the scanning microscope were presented.

The sintered steel (M3:2+TiN) was more resistant to wear than the cast steel (M2+TiN). In the case of blanking with the $8 \%$ clearance small flank surface wear occurred, the coating was undamaged except a few long grooves. The hard incisions in blanking materials scratched the punch surfaces until the grooves occurred. There were coating spalling, in small zones, which caused the punch material unleashing along the grooves line from the cutting edge (Fig. 17b). The punches made of M3:2 material with the TiN coating had a lower wear than punches made of M2 with coating. After 800000 cuts on the M3:2+TiN punch flank surface the scratches were observed (Fig. 17b). At the blanking process beginning the TiN layer separation on the cutting edge side may have occurred. For the punches with that damages the wear process is advancing faster and the coating layer loss is increasing. From the front the flank face has wear lees than in the case of the $0 \%$ blanking clearance. For the blanking process with $0 \%$ clearance the front faces wear is greater than the face wear (Fig. 14d). When the blanking process clearance is set to $8 \%$ the sheared blanks are deflecting and moving along the punch face. Thus the punch face wear is more intensively (Fig. 14c) and the value of the punch edge radius is increasing. The surface degradation for punch made of M3:2+TiN steel (Fig. 17b) is different than in the case of punch made of M2+TiN steel (Fig.16b). Similarly case is for the punches made of M3:2(+TiN) with $0 \%$ blanking clearance (Fig. 17a). High-speed steel (cast steel) is less 

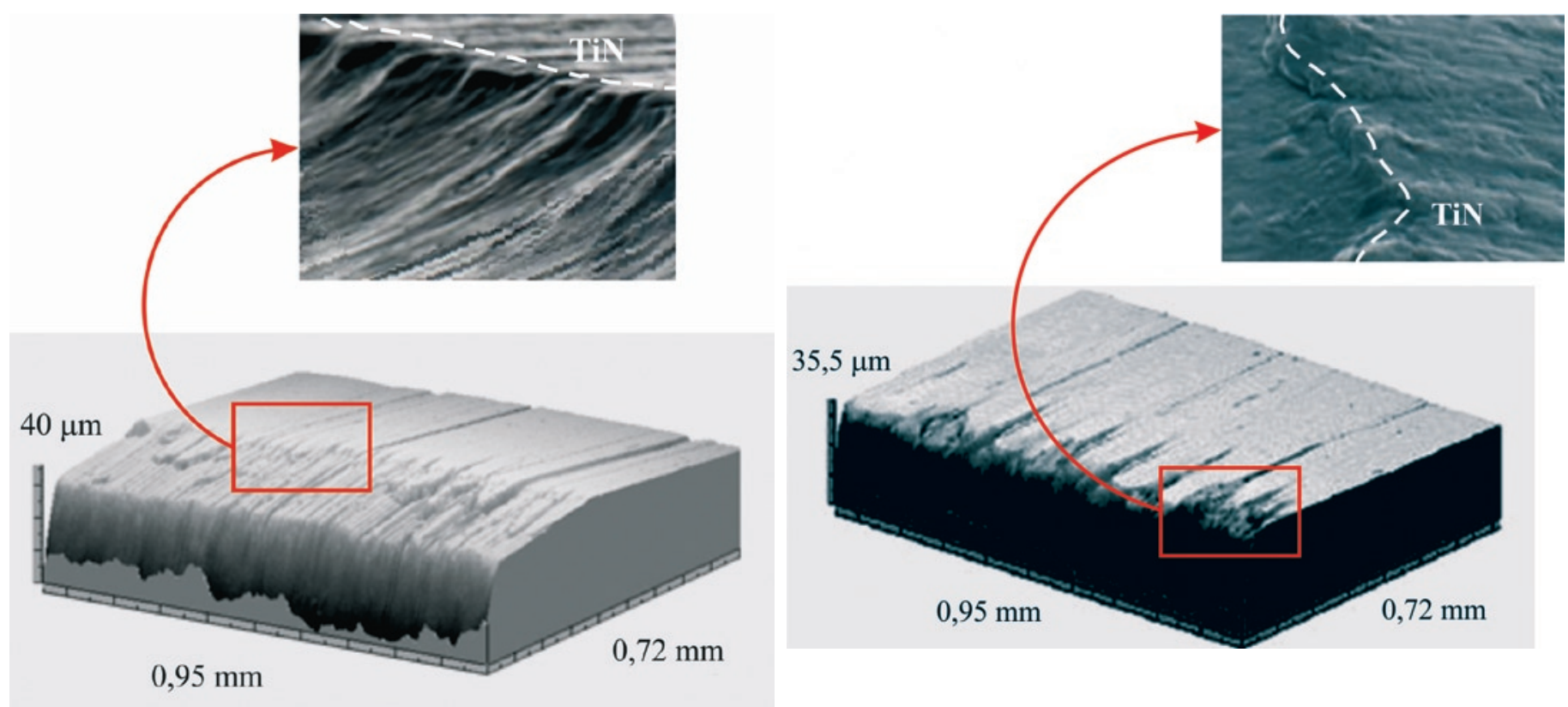

Fig. 16. M2+TiN punch flank surface after 800000 cuts with blanking clearance: a) 0\%, b) 8\%
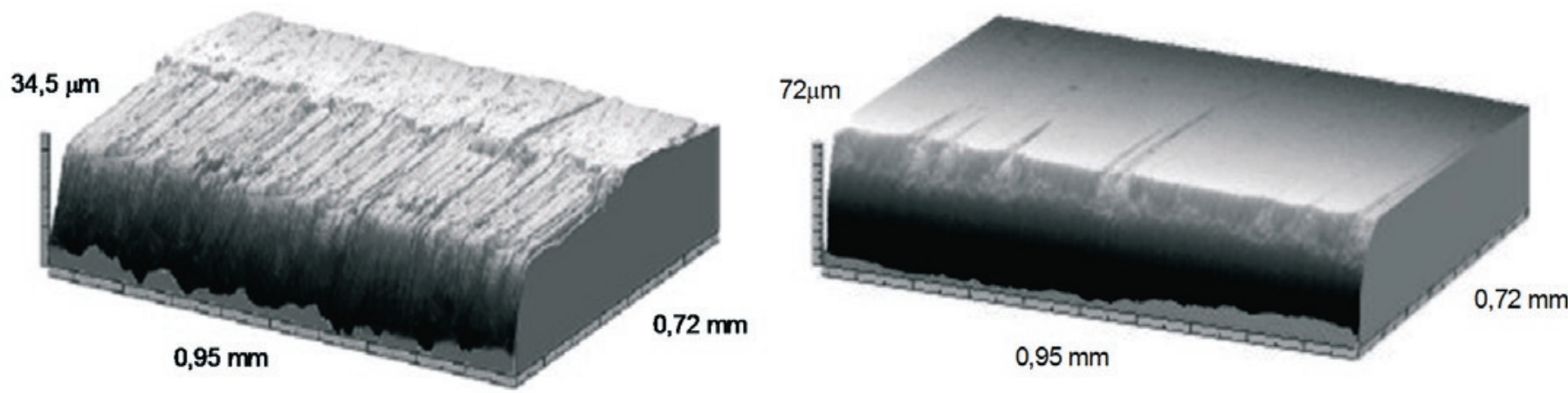

Fig. 17. M3:2+TiN punch flank surface after 800000 cuts with blanking clearance: a) 0\%, b) 8\%

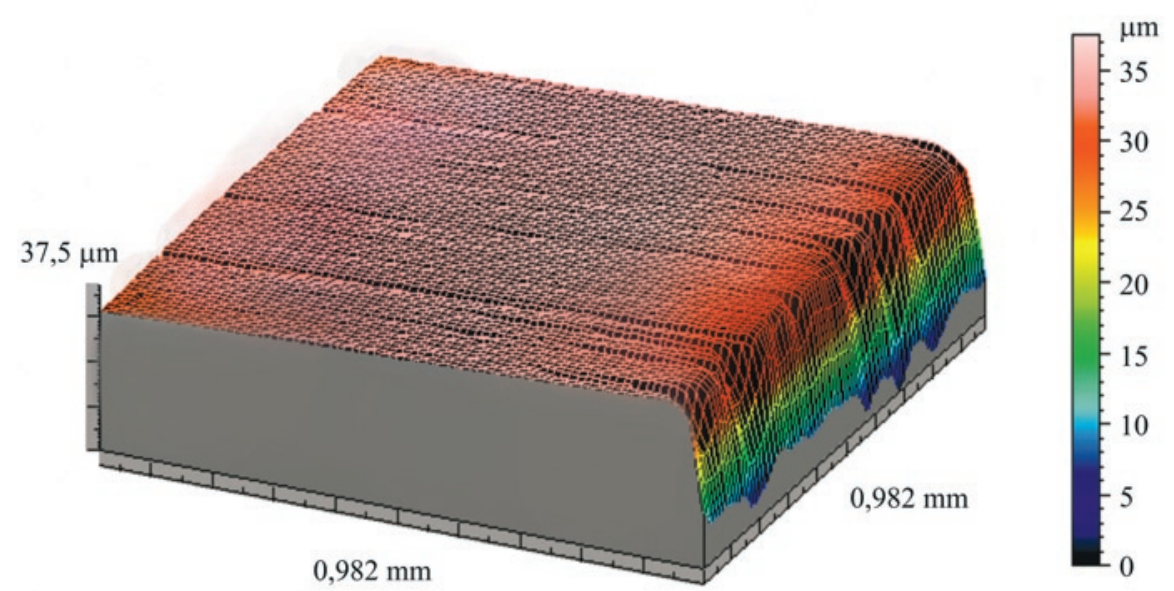

Fig. 18. Cutting edge and punch flank surface after 800000 cuts with blanking clearance $8 \%(M 2+T i N$ punch material)

resistant to ridging. After a certain time the coating layer in zones of strong ridging is spalling (Fig. 16 and Fig. 17). The sintered steel with TiN coating is more resistant to the degradation mechanism.
Applying the coating layer on the tool inhibit the surface wear, but the friction process of the unleashed sheet material and punch surfaces caused the TiN layer spalling and unleashing the punch material. Thus, the coating boundary on the punch surface was changing (Fig. 16b). This coating boundary does not have a linear characteristic and it is not a product of TiN wear but it is caused by lower wear resistance of punch material. Unfortunately, the exploitation of punches with coating losses increases the coating destruction process.

The 3,5 $\mathrm{mm}$ thickness surface punch, made of the M2 with TiN coating, after 800000 cuts was presented in Figure 18. Close to the cutting edge on the flank surface the increased wear was observed (in figure the pink-white color: $36 \div 37$ $\mu \mathrm{m})$. With increasing the distance from the cutting edge the red color becomes more saturated (value of $28 \div 29 \mu \mathrm{m}$ ). The wear size changes on that surface are a few micrometers. This proves the TiN coating wearing out. 


\section{Cutting tools geometry influence on the deformation in sheet material}

\subsection{Microhardness distribution}

During the blanking process there was no spalling or tearing of the C6 class coating despite the sheet material deformation. On both straight line (left in Fig. 19) and curved line of intersection (right in Fig. 19) the coating had a structure coherent with the tool natural material.
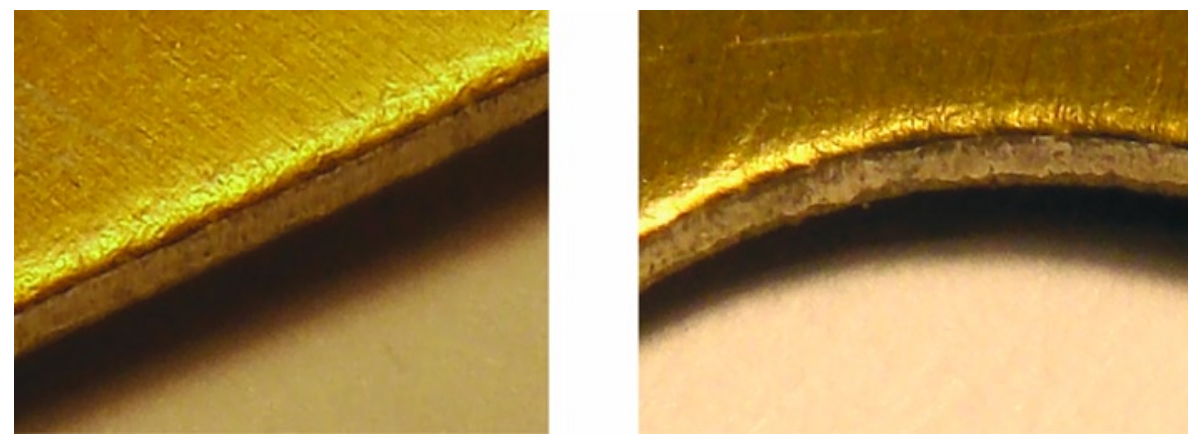

Fig. 19. Silicon steel sheet coating close to the separation surface

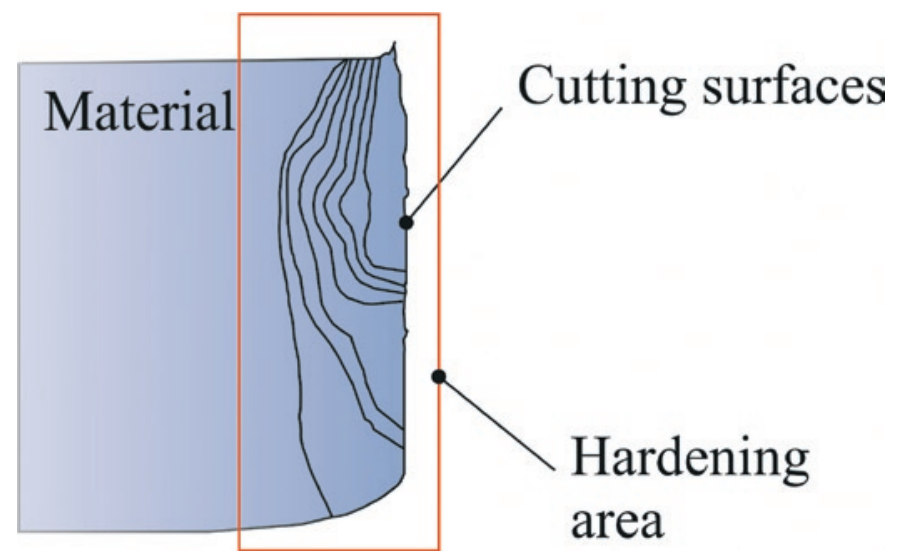

Fig. 20. Test zone of the plastic strain concentration close to the separation surface on the product cross-section

The blanking process with using excessive wear tools is influencing on the size of deformation area in the vicinity of cutting edge. Using indirect method (hardness measurement) the zone of material changes was specified. The hardness was measured by using Matsuzawa Microhardness equipment. Pyramid with $136^{\circ}$ apex angle was used as a penetrator. The measurement were carried out at load of $0,1 \mathrm{~kg}$ (HV0.1) with the penetration time set up to 10 s. Initial hardness before sheet blanking process was 145 HV0.1 (average from 5 measurements). The distance between measuring point was determined on $0,05 \mathrm{~mm}$. In Figure 20 the location of altered microstructure close to the separation surface, as a result of strong punch wear, was presented. During the blanking process the punch cutting edge and flank surface are wear. Thus, the punch-die clearance is increasing, the shear stress directions are changing in accordance with the theoretical separation surface. The tools geometry changes influence on
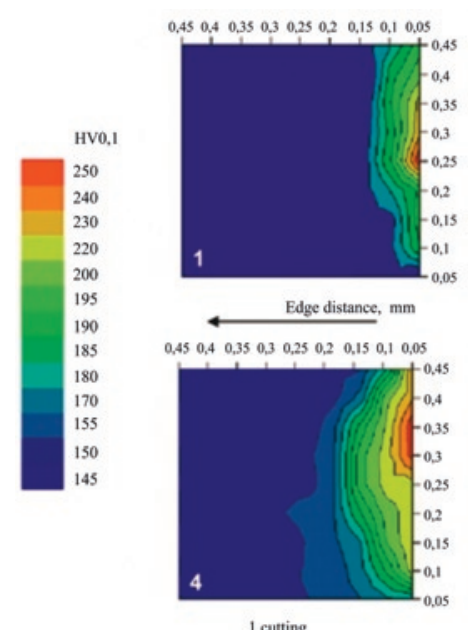

1 cutting the value and size of microhardness changes of the sheet material in vicinity of the cutting line. The hardened layer thickness is related with plastic deformation phase. As the value of plastic deformation is increasing the thickness and hardness increase of strengthened layer is greater.

The maximum increase of material hardness was observed close to the cutting line and more accurately, in the vicinity of the crack initiation (Fig. 21). In all analyzed cross-sections $(1 \div 6)$ the deformed sheets microhardness is about $250 \mathrm{HV} 0.1$. Thus, it is 1,72 times greater than the average hardness of undeformed sheets (145 HV0.1). This hardness increase is determined by large plastic deformations. The material strengthening is so high that the plastic cutting phase is end, and appearing microcracks begin the fracture phase. The microhardness distribution in the vicinity of intersection surface was different for blanking process with $0 \%$ and $8 \%$ of punch-die clearance. The intensity of punch surface wear influences on the value and zone of the microhardness changes. For clearance close to $0 \%$ the zone deformation changes is relatively small (Fig. 21 - 1). It increases with the tool wear (Fig. 21 - 2 and 3). Tool wear during the blanking process significantly increases the zone of plastic strain, and deteriorates the product magnetic properties. In blanking process with $8 \%$ punch-die clearance the zone of plastic deformation (Fig. $21-4,5$, 6 ) is greater than in case with $0 \%$ clearance. The vertical dimension of the microhardness changing zone is greater for greater number of sheared blanks. Tool wear changes the punch-die clearance and thus the material fracture zone is increasing. As the punch-die clearance increased the zone of microhardness changes has also increased. The change of clearance form $0 \%$ to $8 \%$ resulted in almost double enlargement of the hardness changes zone. In the fracture zone a significant hardness increase can be observed, so the volume of material with altered magnetic properties increased.

In the electric motors assembly process it is important that the rotor and stator should be produced as most "packed" block with as small material loss. The burr height is an important issue and it should be relatively small (Fig. 22a). In blanking process with large clearance the elements are produced with larger material loss (Fig. 22b). The material rounding is also high. The strengthening zone and mate-
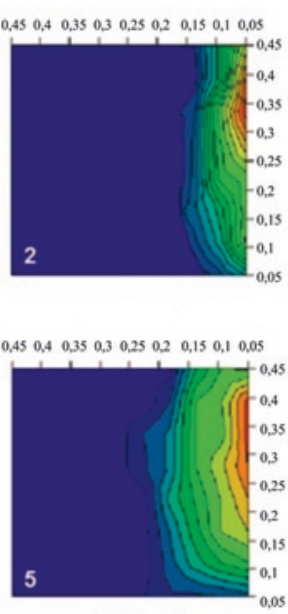

600000 cutting
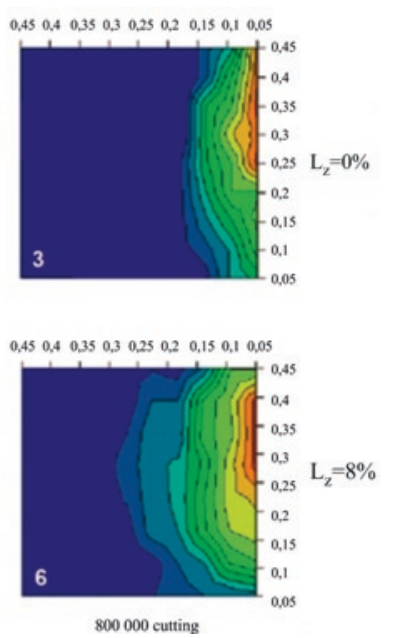

Fig. 21. Microhardness distribution on the part cross-section in vicinity of separation surface for blanking process with $L_{z}=0 \%$ and $8 \%$ punch-die clearance after specified number of cuts 
a)

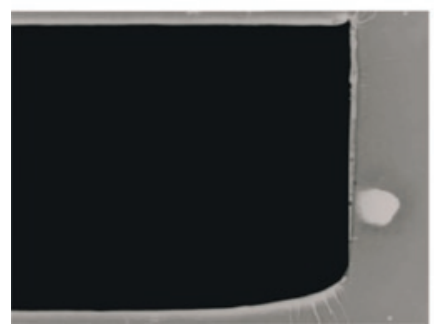

b)

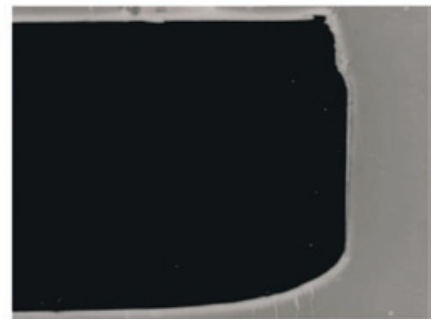

Fig. 22. Part cross-section for initial cuts with blanking clearance a) $0 \%$ and b) $8 \%$

rial loss in vicinity of the separation surface deteriorate the magnetic properties of the rotor and stator $[15,20,25,31 \div 33]$.

\subsection{Stress distribution}

The FEM analysis of blanking process was made to obtain the influence of the tool geometry changes, as a tool wear results, on the stress distribution at the time of initial material fracturing. The punch displacement was determined in experimental research (Fig. 23) [22]. In simulations the medium stress distributions, which determining the place of fracture initiation, were obtained $\left(\mathrm{L}_{\mathrm{z}}=0 \% \rightarrow \mathrm{h}_{\mathrm{s}}=0,41\right.$; $\left.\mathrm{L}_{\mathrm{z}}=8 \% \rightarrow \mathrm{h}_{\mathrm{s}}=0,33\right)$.

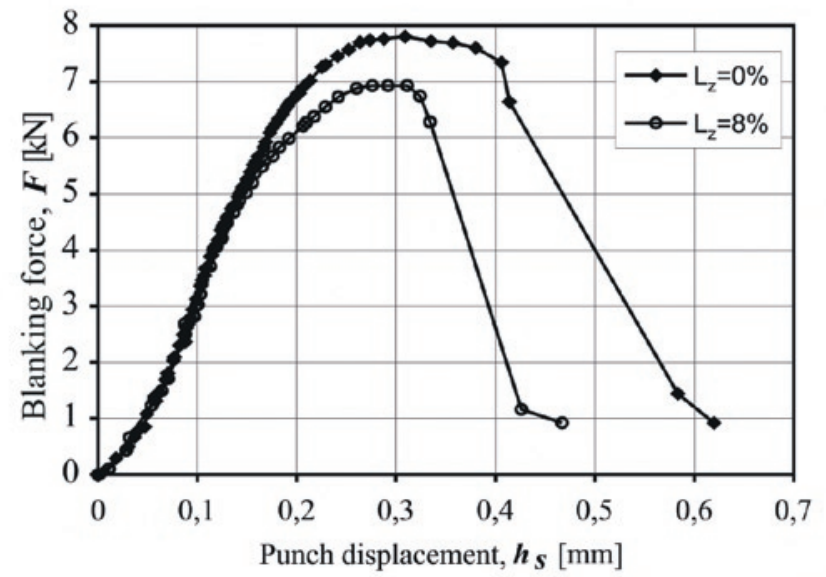

Fig. 23. Force-displacement punch curves during blanking process with different clearance

The blanking process was modeled in MSC. Marc 2010 numerical software. The tool geometry was determined based on the punch wear cutting edge (Fig. 14 and Fig. 24a). The material model was set up as elastic-plastic with nonlinear strengthening with parameters: $\mathrm{C}=627$ $\mathrm{MPa}$ and $\mathrm{n}=0,18$ (Fig. 1). Other parameters used in numerical simulations were presented in Table 1. The friction coefficient was determined at 0,15 . In axial-symmetric model the boundary conditions for the blanking process were defined. The blanking tools were defined as rigid body and the sheet plates as deformable material (Fig. 24b).

The results from the numerical analysis were the same as result from experiment. Due to the blanking tools geometry changes and punch-die clearance changes the stress state and the height of punch penetration before the strengthened material fracture starts are chang-
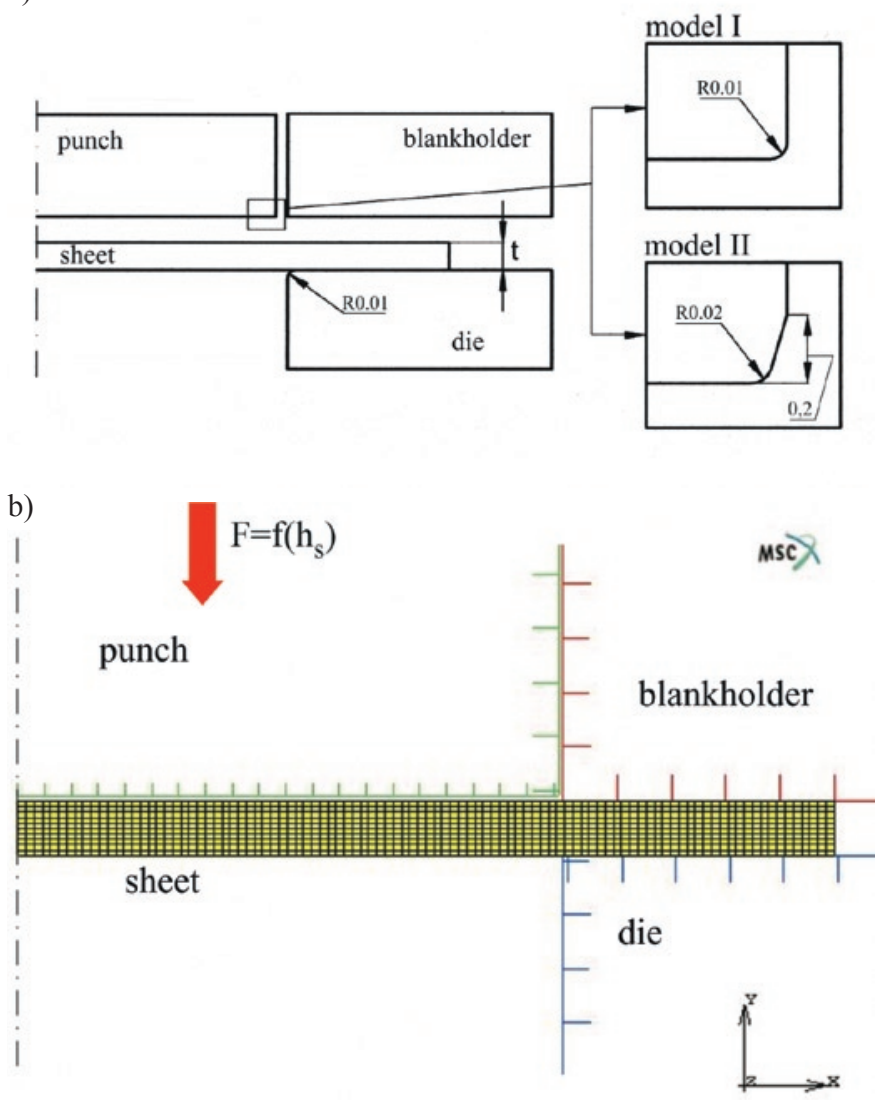

Fig. 24. FEM model assumption: a) punch model variants, b) parts definition

ing (Fig. 25, 26). In the case of sharp-edged tools the stress concentration appeared in the vicinity of punch edge and shearing die (Fig. 25). In simulation of blanking process with using wear punch (model II) the stress concentration with higher value was obtained close to the shearing die edge (Fig. 26). The stress values in the vicinity of punch edge were lower than stress values close to the shearing die edge. Due to the change of the distance between the punch cutting edge and shearing die edge the stress state on the principal directions is changing, so the average stress values are also changing.

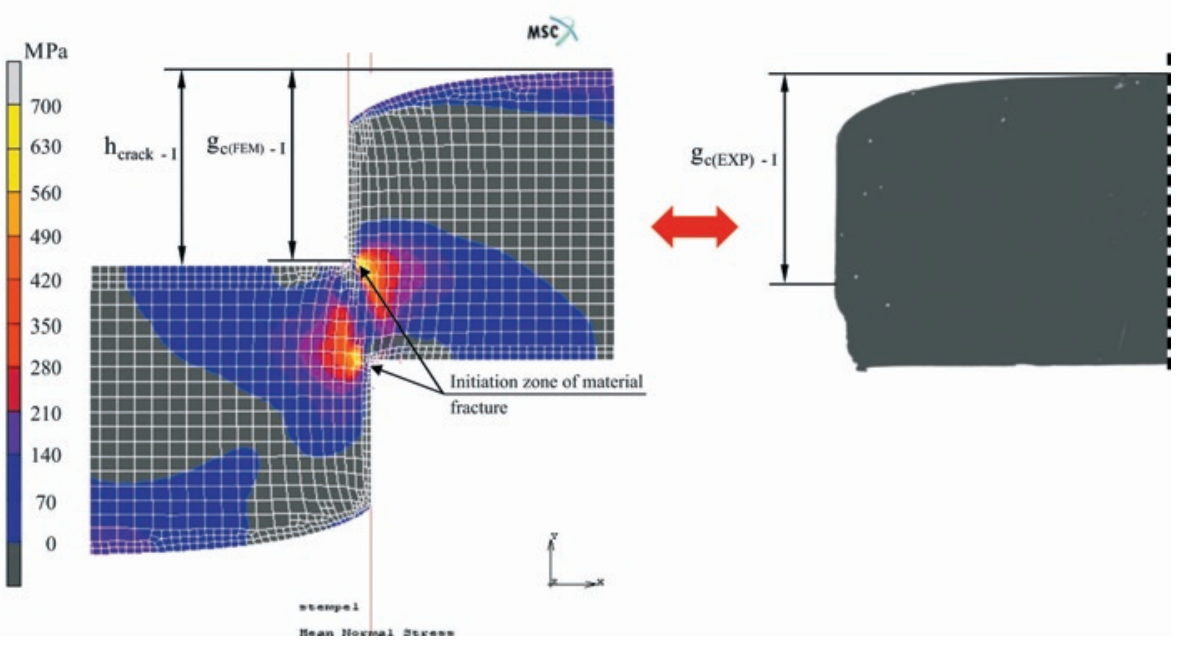

Fig. 25. Average stress distribution at the sheet material fracture phase beginning(a) and the rotor plate cross-section close to the separation surface (b) $-\left(r_{s}, r_{m}=0,01 \mathrm{~mm}, L_{z}=8 \%\right.$, at the first cuts, model I) 


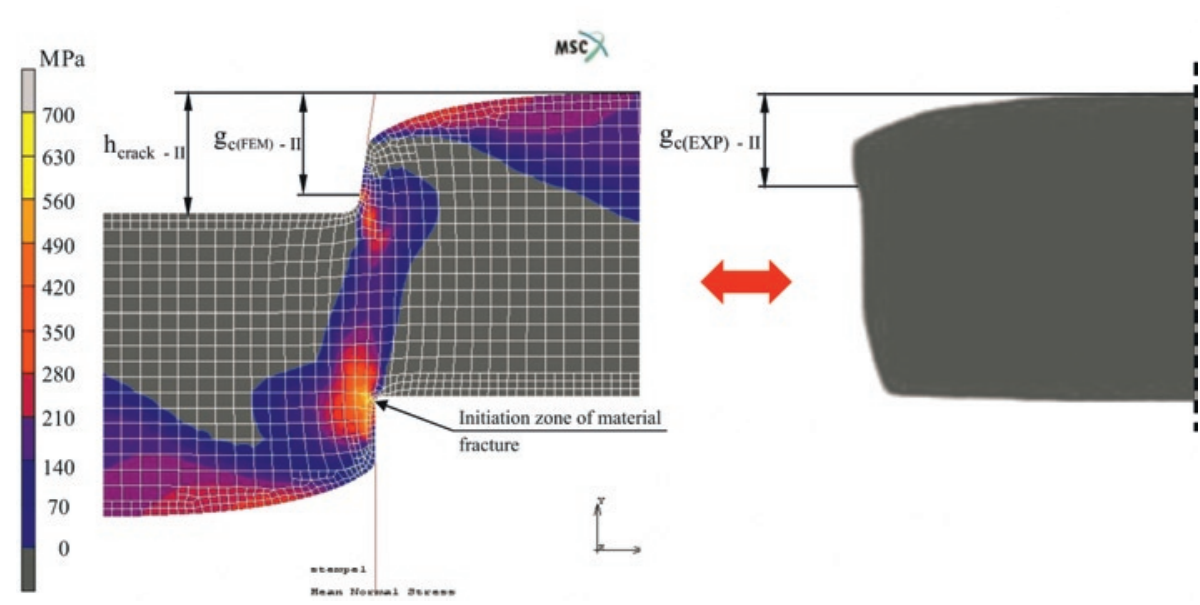

Fig. 26. Average stress distribution at the sheet material fracture phase beginning during the blanking process by punch with determined wear (a) and the rotor plate cross-section close to the separation surface (b) - ( $L_{z}=0 \%$, after 800000 cuts; II model)

The material and magnetic degradation on the electrical silicon steel sheets edges can not be neglected in the design process of electrical machines. Although, the sheet material magnetic properties changes are less significant for the transformers, but for the electrical machines with rotating magnetic field can result in the greater level of core losses 25,30$]$.

\section{Conclusions}

The tools with TiN coating applications in generator sheet blanking process resulted in a significant increasing of the tools durability. It also reduced the zone of the sheet strengthening. The size of punch-die clearance clearly affects the cutting edges wear intensity and the quality of sheared blanks.

- For the $\mathrm{L}_{\mathrm{z}}=0 \%$ clearance the cutting edge wear is advancing faster, the zone of plastic deformation is reduced and the cutting zone is increased.

- Blanking process with $\mathrm{L}_{\mathrm{z}}=8 \%$ clearance results in less wear of the punch, but the quality of the separation surface is reduced and the plastic deformation zone is increased.

- The tool wear mechanism depends on the punch-die clearance. For the M530-50A steel sheet in blanking process with $8 \%$ clearance the cutting edge rounding was significant increased. And for the $0 \%$ clearance the cutting edge rounding was increasing, but also the material losses on the tool flank surface were obtained.

- TiN coating applying on the punch made by M2 and M3:2 steel resulted in increasing of the punch durability during the blanking process with $\mathrm{L}_{\mathrm{z}}=0 \%$ clearance.

\section{References}

1. ASTM A976 - 13. Standard Classification of Insulating Coatings for Electrical Steels by Composition, Relative Insulating Ability and Application. ASTM International, 2013, pages 5.

2. Bać S., Jaworski J., Stachowicz F.: Durability dependence on cutting tool material in blanking process of generator sheet metal. In: Proceedings Conference Technology' 99, Bratislava, Slovak-Republic, 452, 1999.

3. Chumrum P., Koga N., Premanond V.: Experimental investigation of energy and punch wear in piercing of advanced high-strength steel sheet. International Journal of Advanced Manufacturing Technology, 2015: 79: 1035-1042, http://dx.doi.org/10.1007/s00170-015-6902-z.

4. Cheung C.F., Lee W.B., Chiu W.M.: An investigation of tool wear in the dam-bar cutting of integrated circuit packages. Wear, 2000: 237: 274-282, http://dx.doi.org/10.1016/S0043-1648(99)00350-6.

5. Emura M., Landgraf F. J. G., Ross W., Barreta J. R.: The influence of cutting technique on the magnetic properties of electrical steels. Journal of Magnetism and Magnetic Materials, 2003: 254-255: 358-360, http://dx.doi.org/10.1016/S0304-8853(02)00856-9.

6. Gréban F., Monteil G., Roizard X.: Influence of the structure of blanked materials upon the blanking quality of copper alloys. Journal Materials Processing Technology, 2007: 186: 27-32, http://dx.doi.org/10.1016/j.jmatprotec.2006.11.226

7. Golovashchenko S.: A Study on Trimming of Aluminum Autobody Sheet and Development of a New Robust Process Eliminating Burrs and Slivers. International Journal of Mechanical Sciences, 2006: 48: 1384-1400, http://dx.doi.org/10.1016/j.ijmecsci.2006.07.007.

8. Golovashchenko S. F.: Analysis of Trimming of Aluminum Closure Panels. Journal of Materials Engineering and Performance. 2007: 16: 213-219, http://dx.doi.org/10.1007/s11665-007-9034-2.

9. Golovashchenko S. F.: Quality of Trimming and its Effect on Stretch Flanging of Automotive Panels. Journal of Materials Engineering and Performance, 2008: 17: 316-325, http://dx.doi.org/10.1007/s11665-008-9220-x.

10. Guo W., Tam H.-Y.: Effects of extended punching on wear of the WC/Co micropunch and the punched microholes. International Journal of Advanced Manufacturing Technology, 2012: 9: 955-960, http://dx.doi.org/10.1007/s00170-011-3567-0.

11. Hernández J.J., Franco P., Estrems M., Faura F.: Modelling and experimental analysis of the effects of tool wear on form errors in stainless steel blanking. Journal Materials Processing Technology, 2006: 180: 143-150, http://dx.doi.org/10.1016/j.jmatprotec.2006.05.015.

12. Hu D.-Ch., Chen M.-H., Ouyang J.-D., Yin L.-M.: Finite element analysis of the thermal effect in high-speed blanking of thick sheet metal. International Journal of Advanced Manufacturing Technology, 2015: 80: 1481-1487, http://dx.doi.org/10.1007/s00170-015-6954-0.

13. Jasiński W., Zawada P.: The investigation of discreteness in material of catalytic pipes by the eddy current method. Eksploatacja $\mathrm{i}$ Niezawodnosc - Maintenance and Reliability, 2003: 2: 28-30.

14. Jeong H., Ha J., Hwang J., Lee H., Kim D., Kim N.: A study on the shearing process and the burr formation of zircaloy-4 sheet by using GTN model. International Journal of Precision Engineering and Manufacturing, 2014: 15: 2167-2175, http://dx.doi.org/10.1007/s12541014-0578-4.

15. Kedous-Lebouc A., Cornut B., Perrier J. C., Manfé P., Chevalier T.: Punching influence on magnetic properties of the stator teeth of an induction motor. Journal of Magnetism and Magnetic Materials, 2003: 254-255: 124-126, http://dx.doi.org/10.1016/S0304-8853(02)00803-X.

16. Klingenberg W., de Boer T.W.: Condition-based maintenance in punching/blanking of sheet metal. International Journal of Machine Tools and Manufacture, 2008: 48: 589-598, http://dx.doi.org/10.1016/j.ijmachtools.2007.08.013.

17. Levy B. S., Van Tyne C. J.: Review of the Shearing Process for Sheet Steels and Its Effect on Sheared-Edge Stretching. Journal of Materials Engineering and Performance, 2012: 21: 1205-1213, http://dx.doi.org/10.1007/s11665-011-9997-x. 
18. Lo S-P., Chang D-Y., Lin Y-Y.: Quality prediction model of the sheet blanking process for thin phosphorous bronze. Journal of Materials Processing Technology, 2007: 194: 126-133, http://dx.doi.org/10.1016/j.jmatprotec.2007.04.110.

19. Makich H., Carpentier L., Monteil G., Roizard X., Chambert J., Picart P.: Metrology of the burr amount - correlation with blanking operation parameters (blanked material - wear of the punch). International Journal of Material Forming, 2008: 1: 1243-1246, http://dx.doi.org/10.1007/ s12289-008-0167-0.

20. Moses A. J., Derebasi N., Loisos G., Schoppa A.: Aspects of the cut-edge effect stress on the power loss and flux density distribution in electrical steel sheets. Journal of Magnetism and Magnetic Materials, 2000: 215-216: 690-692, http://dx.doi.org/10.1016/S0304-8853(00)00260-2.

21. Mubarak A., Akhter P., Hamzah E., Radzi M., Toff M.R.HJ.M., Qazi I. A.: Effect of coating thickness on the properties of tin coatings deposited on tool steels using cathodic arc pvd technique. Surface Review and Letters, 2008: 4: 401-410, http://dx.doi.org/10.1142/ S0218625X08011524.

22. Mucha J., Stachowicz F.: Effect of clearance of blanking of generator sheets - experimental investigation and numerical simulation. Acta Mechanica Slovaca, 2004: 8: 301-306.

23. Mucha J.: An effect of selected parameters on shearability of the EP-530-50A. Rudy i Metale Nieżelazne, 2004: 1: 23-26 (in Polish).

24. Mucha J.: The analysis of selected material suitability for tools used for blanking the commutator motor elements. In: Proceedings 9th International Scientific Conference, Applied Mechanics, Ostrawa, VŠB-Technical University of Ostrawa, Czech Republic, 171-172, 2007.

25. Oka M., Kawano M., Shimada K., Kai T., Enokizono M.: Evaluation of the Magnetic Properties of the Rotating Machines for the Building Factor Clarification. Przegląd Elektrotechniczny, 2011: 9b: 43-46.

26. PN-EN 10106:2016-01. Taśmy i blachy stalowe elektrotechniczne o ziarnie niezorientowanym walcowane na zimno, dostarczane w stanie w pełni przetworzonym. PKN, 2016, stron 24.

27. Ponnaluri S.V., Cherukuri R., Molian P. A.: Core loss reduction in grain-oriented silicon steels by excimer laser scribing. Part I: experimental work. Journal of Materials Processing Technology, 2001: 112: 199-204, http://dx.doi.org/10.1016/S0924-0136(01)00573-8.

28. Raulea LV, Goijaerts AM, Govaert LE, Baaijens FPT (2001) Size effects in the processing of thin metal sheets. J Mater Process Technol 115:44-48, http://dx.doi.org/10.1016/S0924-0136(01)00770-1.

29. Slavic J., Bolka S., Bratus V., Boltezar M.: A novel laboratory blanking apparatus for the experimental identification of blanking parameters. Journal of Materials Processing Technology, 2014: 214: 507-513. http://dx.doi.org/10.1016/j.jmatprotec.2013.10.006

30. Tekiner Z., Nalbant M., Gürün H.: An experimental study for the effect of different clearances on burr, smooth-sheared and blanking force on aluminium sheet metal. Materials and Design, 2006: 27: 1134-1138, http://dx.doi.org/10.1016/j.matdes.2005.03.013.

31. Wilczyński W.: Influence of magnetic circuit production for their magnetic properties. Journal of Materials Science, 2003: 38: 4905-4910, http://dx.doi.org/10.1023/B:JMSC.0000004412.94057.47.

32. Yashiki H., Kaneko T.: Effect of alloying elements on response of nonoriented electrical steels to stamping operations. Journal of Materials Engineering and Performance, 1992: 1: 29-34, http://dx.doi.org/10.1007/BF02650029.

33. Żurek Z. H., Kurzydłowski K. J., KUKLA D., BARON D., Material Edge Conditions of Electromagnetic Silicon Steel Sheets. Przegląd Elektrotechniczny, 2013: 2b: 112-115.

\author{
Jacek MUCHA \\ Rzeszow University of Technology \\ Department of Mechanical Engineering \\ al. Powstańców Warszawy 8 \\ 35-959 Rzeszów, Poland
}

Jan JAWORSKI

Rzeszow University of Technology

Department of Manufacturing Processes and Production Engineering

al. Powstańców Warszawy 8

35-959 Rzeszów, Poland

E-mails: j_mucha@prz.edu.pl, jjktmiop@prz.edu.pl 